to decisions on treatment. Thirdly, meta-analyses should incorporate estimates of the risk in the included trials to examine whether systematic differences in benefit are seen in relation to the degree of risk of participants in the trials. ${ }^{8}$ Finally, since those who gain the most from medical treatment are those who have most to gain, the irrationality of current suggestions that population groups at increased risk of disease - such as smokers-should not be treated should be recognised.

GEORGE DAVEY SMITH

Department of Public Health,

Senior lecturer in epidemiology and public health

University of Glasgow,

Glasgow G12 8RZ

Department of Social and Preventive Medicine,

MATTHIAS EGGER

Senior research fellow

University of Berne,

CH-3012 Berne,

Switzerland

1 Laupacis A, Sackett DL, Roberts RS. An assessment of clinically useful measures of the consequences of treatment. N Engl f Med 1988;318:1728-33.

2 Antiplatelets Trialists' Collaboration. Collaborative overview of randomised trials of antiplatelet therapy. I. Prevention of death, myocardial infarction, and stroke by prolonged antiplatelet therapy in various categories of patients. $B M 7$ 1994;308:81-106.

3 McInnes GT. Results of trials of antihypertensive therapy: a plan for action. In: Lorimer AR, Shepherd J, eds. Preventive cardiology. Oxford: Blackwell Scientific, 1991: 107-35.

4 Strasser T. Equal blood pressure levels carry different risks in different risk factor combinations. f Hum Hypertens 1992;6:261-4.

5 Alderman MH. Blood pressure management: individualized treatment based on absolute risk and the potential for benefit. Ann Intern Med 1993;119:329-35

6 Collins R, Peto R, MacMahon S, Herbert P, Fiebach NH, Eberlein KA et al. Blood pressure, stroke, and coronary heart disease. Part 2. Short-term reductions in blood pressure: overview of randomised drug trials in their epidemiological context. Lancet 1990;335:827-38.

7 SHEP (Systolic Hypertension in the Elderly Program) Cooperative Research Group. Prevention of stroke by antihypertensive drug treatment in older persons with isolated systolic hypertension. IAMA 1991;265:3255-64.

8 Davey Smith G, Song F, Sheldon TA. Cholesterol lowering and mortality: the importance of considering initial level of risk. $B M 9$ 1993;306:1367-73.

9 Rose G. Sick individuals and sick populations. Int $\mathcal{F}$ Epidemiol 1985;14:32-8.
10 Oliver MF. Risks of correcting risks of coronary disease and stroke with drugs. $N$ Engl $f$ Med 1982;306:297-8.

11 Horton R. Attacks on heart disease. Lancet 1993;342:1291-2.

12 CONSENSUS (Cooperative North Scandinavian Enalapril Survival Study) Trial Study Group. Effects of enalapril on mortality in severe congestive heart failure. $N$ Engl f Med 1987;316: 1429-35.

13 SOLVD (Studies of Left Ventricular Dysfunction) Investigators. Effect of enalapril on survival in patients with reduced left ventricular ejection fractions and congestive heart failure. N Engl f Med 1992;325:293-302.

14 SOLVD (Studies of Left Ventricular Dysfunction) Investigators. Effect of enalapril on mortality and the development of heart failure in asymptomatic patients with reduced left ventricular ejection fractions. N Engl 9 Med 1992;327:685-91.

15 Pfeffer MA, Braunwald E, Moyé LA, Basta L, Brown EJ, Cuddy TE, et al. Effect of captopril on mortality and morbidity in patients with left ventricular dysfunction after myocardial infarction. N Engl F Med 1992;327:669-77.

16 AIRE (Acute Infarction Ramipril Efficacy) Investigators. Effect of ramipril on mortality and morbidity of survivors of acute myocardial infarction with clinical evidence of heart failure. Lancet 1993;342:821-8.

17 Fischl MA, Richman DD, Griego MH, Gottlieb MS, Volberding PA, Laskin OL, et al. The efficacy of azidothymidine (AZT) in the treatment of patients with AIDS and AIDS-related complex. N Engl f Med 1987;317:185-91.

18 Aboulker J-P, Swart AM. Preliminary analysis of the Concorde trial. Lancet 1993;341:889-90.

19 Hamilton JD, Hartigan PM, Simberkoff MS, Day PL, Diamond GR, Dickinson GM, et al. A controlled trial of early versus late treatment with zidovudine in symptomatic human immunodeficiency virus infection. Results of the Veterans Affairs cooperative study (see comments). N Engl f Med 1992;326:437-43.

20 Merigan TC, Amato DA, Balsley J, Power M, Price WA, Benoit S, et al. Placebo-controlled trial to evaluate zidovudine in treatment of human immunodeficiency virus infection in asymptomatic patients with hemophilia. NHF-ACTG 036 Study Group. Blood 1991;78:900-6

21 Fischl MA, Richman DD, Hansen N, Collier AC, Carey JT, Para MF, et al. The safety and efficacy of zidovudine (AZT) in the treatment of subjects with mildly symptomatic human immunodeficiency virus type 1 (HIV) infection. A double-blind, placebo-controlled trial. The AIDS Clinical Trials Group (see comments). Ann Intern Med 1990;112:727-37.

22 Volberding PA, Lagakos SW, Koch MA, Pettinelli C, Myers MW, Booth DK, et al. Zidovudine in asymptomatic human immunodeficiency virus infection. A controlled trial in persons with fewer than 500 CD4-positive cells per cubic millimeter. The AIDS Clinical Trials Group of the National Institute of Allergy and Infectious Diseases. N Engl f Med 1990;322:941-9.

23 Oddone EZ, Cowper P, Hamilton JD, Matchar DB, Hartigan P, Samsa G, et al. Cost effectiveness analysis of early zidovudine treatment of HIV infected patients. $B M \Im$ 1993;307:1322-5.

24 Naylor CD, Chen E, Strauss B. Measured enthusiasm: does the method of reporting trial results alter perceptions of therapeutic effectiveness?. Ann Intern Med 1992;117:916-21.

25 National Cholesterol Education Program Expert Panel on Detection, Evaluation, and Treatment of High Blood Cholesterol in Adults. Report. Arch Intern Med 1988;148:36-69

26 McIsaac WJ, Naylor CD, Basinski A. Mismatch of coronary risk and treatment intensity under the national cholesterol education programm guidelines. 7 Gen Intern Med 1991;6:518-23

27 Expert Panel on Detection Evaluation and Treatment of High Blood Cholesterol in Adults. Summary of the second report of the national cholesterol education program (NCEP) expert panel on detection, evaluation, and treatment of high blood cholesterol in adults (adult treatment panel on detection, evaluation, and

28 Jackson R, Barnham P, Bills J, Birch T, McLennan L, MacMahon S et al. Management of raised blood pressure in New Zealand: a discussion document. BMf 1993;307:107-10.

\title{
IgA nephropathy
}

\section{The commonest form of glomerulonephritis in industrialised countries}

Since idiopathic IgA nephropathy was first reported a quarter of a century ago it has evolved from being a curiosity to becoming the commonest form of glomerulonephritis in industrialised countries. A recent international meeting held to mark the 25 years of study of IgA nephropathy concentrated on its aetiology and pathogenesis but had also to acknowledge that nephrologists still do not know how to treat the disease. ${ }^{1}$

Clinical observation over two decades has shown that spontaneous remission may occur but that $15-20 \%$ of patients develop end stage renal failure within 10 years of diagnosis. The risk factors for progression are impaired renal function at presentation, heavy proteinuria, hypertension, and (curiously) absence of the typical symptom-recurrent macroscopic haematuria. The systemic nature of IgA nephropathy is shown convincingly by its recurrence in patients who receive a kidney transplant and, more remarkably, by the disappearance of IgA deposits when a kidney from someone with the disease is inadvertently transplanted into someone with renal failure from another cause.

When IgA nephropathy was first described, IgA itselfand the fact that it was produced by mucosal cells-had been discovered only a few years earlier. The deposition of this immunoglobulin in glomeruli was explained as an immune complex disease in which an antigen or antigens came into contact with the mucosa and induced an IgA antibody response. This led to antigen-antibody complexes circulating and being deposited in the kidneys. In some patients the serum IgA has an increased antibody activity against food antigens such as gliadin and casein and the amount of circulating complexes is increased, but these are not consistent findings. Nor is there good evidence that the mucosal surfaces are incompetent at one of their normal taskspreventing antigen or antigen-antibody complexes from entering the circulation. As with any disease of unknown cause that is mediated by the immune system, autoimmunity was invoked. Some support came from the finding that in some patients serum IgA is bound to fibronectin or collagen, both of which are normal constituents of glomeruli; but this binding was later shown not to be an antigen-antibody combination.

Meanwhile, the physiology and structure of IgA became better understood. It may still be insufficiently known that bone marrow, which produces immunoglobulins, accounts for one third of normal production of IgA. Patients with $\operatorname{IgA}$ nephropathy produce excess amounts of $\operatorname{IgA}$ in their bone marrow $^{2}$ - an observation that underlines the systemic nature of IgA nephropathy. B cells in the tonsils have also been 
shown to produce excess IgA. ${ }^{3}$ The abnormal production seems, then, to affect both the mucosal and non-mucosal compartments. The IgA in the serum of patients also differs qualitatively from that in normal subjects, and these differences are reflected in the IgA deposited in the kidneys: it has an increased negative charge and an increased ratio of $\lambda$ to $\kappa$ light chains, and its carbohydrate content is abnormal-a portion is galactose deficient. IgA eluted from glomeruli and in the circulating complexes is polymeric and of the $\operatorname{IgA}$ subclass; the other subclass, $\operatorname{IgA} \mathrm{A}_{2}$, which is mainly produced in mucosae, is not found. The meaning of these findings is not clear.

The failure to detect $\operatorname{IgA} A_{2}$ suggests that the main source of glomerular IgA is not mucosal. It may be the physical changes in the IgA molecule that increase its deposition in and reduce its clearance from the glomeruli, which have receptors that bind to the heavy chain of IgA. The differences in the charge and class of IgA in IgA nephropathy might be explained by a particular antigen or antigens driving the selection of $B$ cells that produce IgA, or some dysregulation of production of IgA producing excess IgA, with these characteristics.

How might this dysregulation occur? Again, two possibilities can be considered. The first is through $\mathrm{T}$ cell activity, which influences the production of $\operatorname{IgA}$ by $B$ cells in various ways. Several interleukins (produced by $\mathrm{T}$ cells) regulate production of immunoglobulin, and among these is interleukin 6, which increases production of IgA. Increased concentrations of interleukin 6 have been found in the blood and urine of patients with IgA nephropathy. A second possibility is that the dysregulation of production of $\operatorname{IgA}$ is genetic. Research studies have given conflicting results. Genetic dysregulation would fit with the familial incidence of IgA nephropathy and the abnormalities of production of IgA in healthy relatives of patients.

One way forward in understanding a human disease is to study an animal model. Several models of glomerular deposition of IgA have been developed, but the animals mostly do not develop glomerulonephritis, and the results are not yet answering fundamental questions.

With all these uncertainties about the aetiology and pathogenesis of this disease, can it be treated? Neither prevention nor cure is yet possible, but rigorous treatment of hypertension will slow progression of the disease, as it will for any chronic renal disease. The therapeutic reflex to treat any "immune" disease with immunosuppressive drugs has largely been unfruitful: the two exceptions are the uncommon acute crescentic variety of IgA nephropathy and some recent evidence that alternate day treatment with prednisone may slow progression. ${ }^{5}$ Phenytoin has the curious property of diminishing serum concentrations of IgA. A trial of this drug in 1980 showed no benefit, ${ }^{6}$ but recent long term follow up of the cohorts has suggested that progression of IgA nephropathy may have been slowed.

Tonsillectomy has been recommended with the aim of removing a source of increased production of IgA or a portal of entry of antigen driving production of $\operatorname{IgA}$, or possibly both, and this might stabilise the renal disease. Certainly the serum concentration of IgA does indeed fall postoperatively. ${ }^{7}$ Prospective trials to evaluate these measures are now needed. Secondary IgA nephropathy-which is associated with such conditions as ankylosing spondylitis, coeliac disease, dermatitis herpetiformis, and, most recently, AIDS-does not seem to respond to treatment available for the underlying disorder.

Possibly the immunohistological diagnosis of idiopathic IgA nephropathy is simply a renal phenotype that represents several different disorders. Let us hope, then, that when the time comes for the 50th anniversary of IgA nephropathy the idiopathic form will have disappeared from our terminology and that specific treatments-for example, to eliminate particular B cell clones that produce IgA - will be available.

D GWYN WILLIAMS

Renal Unit,

Professor of medicine

Division of Medicine,

United Medical and Dental Schools of Guy's

and St Thomas's Hospitals,

Guy's Hospital,

London SE1 9RT

1 IgA nephropathy: the 25th year. Contrib Nephrol 1993;1-219.

2 Van den Wall Bakke AWL, Daha MR, Radl J, Haaijman J, Van der Ark A, Valentijn RM, et al. The bone marrow as production site of the IgA deposited in the kidneys of patients with IgA nephropathy. Clin Exp Immunol 1988;72:321-5.

3 Egido J, Biasco R, Lozano J, Sancho J, Garcoa-Hoyo R. Immunological abnormalities in the tonsils of patients with IgA nephropathy: inversion in the ratio of IgA:IgG bearing lymphocytes and increased polymeric IgA synthesis. Clin Exp Immunol 1984;57:101-6

4 Williams DG. Pathogenesis of idiopathic IgA nephropathy. Pediatr Nephrol 1993;7:303-11.

Bruce JA, Barker C. Alternate-day prednisone therapy in IgA nephropathy. Contrib Nephrol 1993;104:198-206.

6 Clarkson AR, Seymour AE, Woodroffe A J, McKenzie PE, Chan Y-L, Wootton AM. Controlled trial of phenytoin therapy in IgA nephropathy. Clin Nephrol 1980;13:215-8.

Bene MC, Hurault de Ligny B, Kessler M, Foliguet, Faure GC. Tonsils in IgA nephropathy. Contrib Nephrol 1993;104:153-61.

\section{Sunburn and melanoma: how strong is the evidence?}

\section{$A$ history of frequent sunburn modestly increases the risk of melanoma}

Melanoma-both its incidence and its mortality-has been increasing in many populations around the world recently. ${ }^{1}$ Even higher rates have been predicted as a result of the depletion of stratospheric ozone. ${ }^{2}$ Many agencies around the world are now developing programmes to prevent melanoma in the future. For example, the control of skin cancer (including melanoma) is included as one of the targets in the Health of the Nation. ${ }^{3}$

Preventing disease relies on knowing both its cause and practical and cheap ways of either avoiding the cause or blocking its effect. Most people attribute the rising incidence of melanoma to social and behavioural changes this century that have resulted in increased exposure to sunlight. ${ }^{4}$ The fashion for a suntan, associated with increasing public acceptance of decreasing proportions of the body being covered while outdoors, has led to large numbers of people being exposed to sufficient sunlight to cause sunburn during leisure hours. ${ }^{5}$

Exposures sufficient to cause sunburn, particularly in childhood, have been targeted by most educational programmes as the main changeable component in the process that leads to melanoma in people who are constitutionally predisposed to develop it. ${ }^{6}$ But just how strong is the evidence that exposure that is sufficient to cause sunburn is a risk factor for melanoma?

The epidemiological evidence linking sunburn with 